\title{
Laboratory Testing for Bacteria, Virus, or Mycoplasma
}

National Cancer Institute

\section{Source}

National Cancer Institute. Laboratory Testing for Bacteria, Virus, or Mycoplasma. NCI

Thesaurus. Code C113021.

Testing of specimens or materials for the presence of microbial contamination. 